\title{
Alteration-weakening leading to localized deformation in a damage aureole adjacent to a dormant shear zone
}

\author{
Nils R. Backeberg, ${ }^{*}$, Christie D. Rowe ${ }^{\mathrm{a}}$, Naomi Barshi ${ }^{\mathrm{a}}$ \\ ${ }^{a}$ Earth \& Planetary Sciences, McGill University, Montréal, QC, H3A 0E8, Canada
}

\begin{abstract}
Deformation adjacent to faults and shear zones is traditionally thought to correlate with slip. Inherited structures may control damage geometry, localizing fluid flow and deformation in a damage aureole around structures, even after displacement has ceased. In this paper we document a post-shearing anastomosing foliation and fracture network that developed to one side of the Mesoarchean Marmion Shear Zone, which hosts the low-grade, disseminated Hammond Reef gold deposit. The shear zone juxtaposed a greenstone belt against tonalite gneiss and was locked by an intrusion that was emplaced during the final stages of suturing. After cessation of activity, fluids channeled along fault- and intrusion-related fractures led to the pervasive sericitization of feldspars. Sericite-rich foliated zones resulted from flattening in the weakening of the tonalite during progressive alteration without any change in the regional NW-SE shortening direction. The anastomosing pattern may have been inherited from an earlier ductile fabric, but sericite alteration and flattening fabrics all formed post-shearing. Thus, the apparent foliated fracture network adjacent to the Marmion Shear Zone is a second-order effect
\end{abstract}

\footnotetext{
${ }^{*}$ corresponding author: (Email address) nils.backeberg@gmail.com
} 
of shear-related damage, distinct in time from shear activity, adjacent to an effectively dormant shear zone. This phenomenon has implications for understanding the relative timing of fault zone activity, alteration and (in this case) gold mineralization related to long-term fault zone permeability.

Key words: Archean, fault-zones, fluid flow, damage aureoles, alteration

\section{Introduction}

2

Zones of deformation, fluid flow and alteration are commonly observed around major faults and shear zones. In brittle faults, the development of fractured damage zones is attributed to off-fault fracturing associated with fault growth, rupture propagation and stress concentrations caused by geometric heterogeneities in fault systems (Shipton and Cowie, 2003; Mitchell and Faulkner, 2009; Savage and Brodsky, 2011; Johri et al., 2014). In ductile shear zones, strain gradients in the deformation fabrics are related to strain localization around the high-strain core (Coward, 1976; Ramsay, 1980; Mohanty and Ramsay, 1994; Fusseis et al., 2006; Carreras et al., 2010). Major shear zones are known to have a long history of multi-phase deformation, and many studied faults record an evolution from ductile deformation at depth, to later brittle deformation near the surface (Holdsworth et al., 2001; Rutter et al., 2001; Bezerra et al., 2014; Salomon et al., 2015). The deformation zones around faults or shear zones reflect inherited fabrics developed throughout the life of these structures. The fabric development and alteration associated with early deformation may control subsequent structural and geochemical evolution. In this paper, we use the term 'damage aureole' to describe a zone of concentrated deformation fabrics and alteration adjacent to a major fault 
or shear zone, which cannot be described by only brittle fracturing around a fault (c.f. 'damage zone' Cowie and Shipton, 1998; Childs et al., 2009; Savage and Brodsky, 2011). Once established, these damage aureoles may act as a locus for fluid flow and further deformation after activity on the shear zone that formed them has ceased. Therefore, juxtaposition of different periods of deformation can obscure the spacial and temporal link between fault cores and damage aureoles.

In the traditional view, damage zones represent deformation gradients around faults/shear zones and are expressed by distributed small offset fracturing ("damage") during progressive slip along principal slip surfaces (Chester and Logan, 1986; Chester and Chester, 1998; Gudmundsson et al., 2001; Sibson, 2003; Kim et al., 2004). Fractured damage zones typically show a gradually decreasing fracture density away from the fault core (Chester and Logan, 1986; Rawling et al., 2001; Shipton and Cowie, 2003; Faulkner et al., 2003; Mitchell and Faulkner, 2009; Faulkner et al., 2010; Savage and Brodsky, 2011). Fluid flow is controlled by permeability contrasts leading to fluid conduits or barriers, and can be localized or distributed in and around fault zones (Caine et al., 1996; Faulkner et al., 2010). Fault zones and their associated wall-rock damage aureoles influence fluid flow through the crust and allow for deep crustal fluids to move to shallower depths (Sibson et al., 1988; Sibson, 1992; Kennedy et al., 1997; Cox, 2002; Kulongoski et al., 2013). Fluid flow through fault zones is often recorded as hydrothermal alteration of the fault core and wall rock (Goddard and Evans, 1995; Clark et al., 2005; Caine et al., 2010; Morton et al., 2012; Arancibia et al., 2014). Concentrated flow of a fluid through fault zones may also lead to the formation of economic ore 
deposits within the fault core and the surrounding damage aureoles (Vearncombe, 1998; Piessens et al., 2002; Sibson, 2001; Micklethwaite, 2009; Moir et al., 2013).

We present map-scale and microstructural observations of a damage aureole adjacent to the trace of an inferred terrane-bounding shear zone, whose core has been obscured by the intrusion of a granodiorite pluton. The Marmion Shear Zone (MSZ) lies along the western margin of the tonalitegranodiorite Marmion gneiss terrane (Figure 1). The shear zone separates the 3.00 Ga Marmion gneiss from the 3.00 to 2.93 Ga Finlayson Lake greenstone belt (Stone, 2008a, 2010). The Diversion Stock granodiorite intruded along the shear zone and plays an important role in identifying and separating the subtleties of the deformation history and cross-cutting structural fabrics. The damage aureole is developed within the Marmion gneiss, and to a lesser extent, within the Diversion Stock, and hosts the disseminated, low-grade Hammond Reef gold deposit. The damage aureole consists of a fractured and altered zone along the entire length of the terrane boundary with localized foliation zones mapped by Stone (2008a) as a regional anastomosing pattern parallel to the western margin of the Marmion gneiss (Figure 2 ). In the course of a study of the Hammond Reef gold deposit, we discovered a disparity in timing, kinematics, and conditions of deformation between motion on the Marmion Shear Zone and deformation that formed the anastomosing foliated zone adjacent to the terrane boundary. In this paper we relate the observed deformation fabrics in the tonalite - granodiorite rocks to the regional deformation history and describe and discuss the origin of anastomosing foliation in order to explain the seemingly paradoxical relationship 
between the damage aureole and the Marmion Shear Zone.

\section{Geological setting}

The Superior Province of North America is composed of Archean tonalitetrondhjemite-granodiorite (TTG) and greenstone belt terranes. Our study area is located within the south-central portion of the Wabigoon subprovince, which lies immediately to the north of the Quetico subprovince, across the Quetico fault (Figure 1). The Wabigoon subprovince is a mainly Mesoarchean crustal block that has been subdivided into greenstone belt- and TTGdominated terranes (the Marmion, Winnipeg River, eastern Wabigoon and western Wabigoon terranes. See Davis and Jackson, 1988; Tomlinson et al., 2003; Percival, 2007). The onset of deformation in the south-central Wabigoon subprovince has been dated at around $2.92 \mathrm{Ga}$, based on the youngest depositional ages found in greenstone belt terranes (Tomlinson et al., 2003, 2004; Percival, 2007). Younger, east-west trending terrane boundaries across the Superior Province record a progressive north to south amalgamation of subprovinces between 2.72 and 2.68 Ga (Corfu and Stott, 1986; Polat and Kerrich, 2001; Percival et al., 2006; Percival, 2007). The southern margin of the Wabigoon subprovince is the $\sim 2.70$ Ga Quetico fault, which records dextral transpression during accretion of the Quetico and Wawa subprovinces from the south (Corfu and Stott, 1986; Percival and Williams, 1989; Williams, 1990; Bauer et al., 1992; Peterson and Zaleski, 1999), associated with northward subduction of the Wawa subprovince interpreted from northward dipping reflectors in seismic profiles (Calvert et al., 1995; Musacchio et al., 2004). The Marmion Shear Zone juxtaposes the 2.93 Ga Finlayson Lake green- 
stone belt and 3.00 Ga Marmion tonalite gneiss, and has been mapped as the southwestern continuation of the Red Paint Lake Shear Zone (Davis and Jackson, 1988; Stone, 2008a). The shear zone is not exposed and the kinematics have been obscured by the intrusion of the younger Diversion Stock tonalite - granodiorite (Figure 1) and overprinting deformation. Constraints on regional kinematics, and the motion on the Marmion Shear Zone, are therefore compared to the deformation history of the adjoined Finlayson Lake greenstone belt (Backeberg et al., 2014) and Marmion gneiss (this study). We found no other structural studies that constrain Archean kinematics in the area.

Compared to the Marmion gneiss, the Finlayson Lake greenstone belt preserves a more detailed structural and metamorphic history. Here we briefly summarize the deformation history of the Finlayson Lake greenstone belt from Backeberg et al. (2014). A prograde metamorphic assemblage is preserved as aligned inclusions within younger amphiboles $\left(D_{1}\right)$ and records maximum pressures of $820 \pm 40 \mathrm{MPa}$ (depth of $\sim 29 \mathrm{~km}$ ) at $600 \pm 45^{\circ} \mathrm{C}$. The predominant structural fabrics across the greenstone belt correspond to amphibolite facies, $\mathrm{D}_{2}$ peak metamorphism at $625 \pm 25^{\circ} \mathrm{C}$ and $635 \pm 135$ $\mathrm{MPa}$ (depth of $\sim 22 \mathrm{~km}$ ), associated with sinistral transpression and a NNWoriented horizontal shortening axis. During exhumation of the greenstone belt, retrogression of amphibole to chlorite was focused close to the eastern margin of the greenstone belt (i.e. the Marmion Shear Zone). The NE-SW foliation, formed by flattening of quartz and growth of chlorite, records NWSE shortening, perpendicular to the shear zone $\left(\mathrm{D}_{3}\right)$. The flattening and alteration of amphiboles to chlorite overprinted any earlier structural fab- 
rics associated with shearing along the Marmion Shear Zone. The Diversion Stock intruded along the chlorite foliation, suggesting emplacement after $\mathrm{D}_{3}$. Later, $\mathrm{D}_{4}$ brittle faults, sub-parallel to the $\mathrm{D}_{3}$ foliation, cut both along and across the $\mathrm{D}_{3}$ foliation, at quartz-brittle conditions and record the same NWSE shortening. These brittle faults record only $\mathrm{cm}$ - to $\mathrm{m}$-scale displacements and are most abundant along the eastern edge of Finlayson Lake greenstone belt, near the Marmion Shear Zone (Backeberg et al., 2014).

The age of the Marmion Shear Zone is constrained by cross-cutting relations. The upper limit on deformation is the youngest ages of deposition in the Finlayson Lake greenstone belt at $2.93 \mathrm{Ga}$ (Davis and Jackson, 1988; Tomlinson et al., 1999, 2003; Stone, 2008a). The youngest age for any major displacement along the Marmion Shear Zone is constrained by the $\sim 2.70 \mathrm{Ga}$ Quetico fault to the south (Corfu and Stott, 1986; Bauer et al., 1992). An anastomosing network of foliation cross-cuts both the Marmion gneiss and Diversion Stock, parallel to the boundary with the Finlayson Lake greenstone belt (Figure 2). The anastomosing network has also been referred to as the Marmion deformation corridor by the Osisko Mining Corporation and other exploration companies (executive report by Osisko, 2013). Although both the greenstone belt and gneiss terrane have well-developed foliation zones, gold was only deposited in the damage aureole in the tonalite-granodiorite of the Marmion gneiss, forming the Hammond Reef gold deposit (Figure 2).

\section{Geology of the western margin of the Marmion gneiss}

Field data and samples were collected from mapping transects along lakeshore exposures (Figure 2). New structural data was compiled to identify 
structural trends and variations in the observed fabrics. We differentiate structural fabrics related to alteration, pure shear (flattening) and simple shear. In addition, we define a detailed lithological classification to identify Diversion Stock and Marmion gneiss samples (Table 1), as the units have an overlapping lithology and are therefore easily confused in the field. This distinction is important in order to understand the cross-cutting relationships between intrusion, alteration and deformation events. When discussing events common to both the Diversion Stock and Marmion gneiss, we refer to them together as 'the tonalites'.

\subsection{Marmion gneiss}

The Marmion gneiss is a $3.00 \mathrm{Ga}$ tonalite (Stone, 2010) that forms part of a large TTG terrane that covers over $200 \mathrm{~km}^{2}$ (Figure 1). Recent dating reveals a variety of intrusive ages from 3.00 to $2.68 \mathrm{Ga}$ as part of the 'Marmion Intrusive Complex' (MIC, Bjorkman et al., 2015). Published maps describe the Marmion gneiss as either biotite or hornblende-biotite tonalite with a weak gneissosity (Stone, 2008b). This description is a good match to the western part of the terrane, east of the Lynx Head Fault (LHF, Figure 2). We observe aligned hornblende, biotite and sometimes plagioclase augen that define the gneissosity together with weak gneissic banding. Rare folds are observed in the Marmion gneiss, where the gneissosity is more strongly developed. The typical metamorphic assemblage preserved in the Marmion gneiss includes quartz, plagioclase, amphibole and biotite (Table 1). Samples of weakly altered tonalite collected within the alteration corridor and samples eastward away from the western margin, (east of the Lynx Head Fault, Figure 2) have compositions of $A n_{14-20}$. 


\subsection{Diversion Stock tonalite-granodiorite}

The Diversion Stock is up to $2 \mathrm{~km}$ thick and separates the Marmion gneiss from the Finlayson Lake greenstone belt (Figure 2). The Diversion Stock ranges in composition from tonalite to granodiorite and locally contains $\mathrm{K}$ feldspar (microcline), which is absent in the Marmion gneiss (Table 1). The calcium content of plagioclase in the Diversion Stock is low $\left(A n_{02-07}\right)$. The Diversion Stock has not yet been dated, but possibly overlaps with one of the younger intrusive ages in the Marmion Intrusive Complex (between 3.02 and 2.68 Ga, Bjorkman et al., 2015). A lithologically similar intrusive unit, lying between the Marmion gneiss and Lumby Lake greenstone belt to the north, has an U-Pb age of $\sim 2.786 \mathrm{Ga}$ (Buse et al., 2010) and has been mapped as continuous with the Diversion Stock intrusion (see Figure 1). The contact of the Diversion Stock with the Finlayson Lake greenstone belt is a zone of alternating mafic and felsic zones 50 - $100 \mathrm{~m}$ wide. This has been interpreted as felsic dykes of the Diversion Stock, which intruded along the foliation of the greenstone belt (Backeberg et al., 2014). No ductile fabrics, such as gneissic banding, folding or mineral lineations are observed in the Diversion Stock (Table 1).

\subsection{Mafic dykes}

Mafic dykes are common in the Marmion gneiss, but are absent in the Diversion Stock, and are therefore inferred to be Archean in age. These dykes are altered to calcite and chlorite, and are strongly foliated parallel to the terrain boundary, similar to the eastern margin of the Finlayson Lake greenstone belt (Backeberg et al., 2014). 


\subsection{Alteration}

The Marmion gneiss has a higher modal proportion of mafic minerals (10 - $15 \%$ ) compared to the Diversion Stock $(<5 \%)$. In the Marmion gneiss, hornblende and biotite are partially to completely replaced by chlorite within a $2-3 \mathrm{~km}$ wide zone along its western margin, adjacent to the terrane boundary (Figure 2). Hornblende and biotite are better preserved east of the Lynx Head Fault (LHF, Figure 2), which juxtaposes hornblende-biotite tonalite over chlorite-altered tonalite. Chlorite-alteration in the Diversion Stock is less pervasive, and typically only the rims of the hornblende grains are replaced with chlorite, with the core hornblende still preserved (Table 1).

Overlapping with the chlorite-altered zone, we found a variable zone of plagioclase alteration to very fine-grained micas (sericite), epidote and albite. Pyrite is associated with the alteration assemblage of sericitized tonalites. Where plagioclase is partially altered, sericite is concentrated along fractures and grain boundaries (Figure 3a). More intense alteration to sericite partially to completely replaced plagioclase grains, preferentially following twinning and grain boundaries (Figure 3b). Very fine grained relict plagioclase within the sericite altered tonalites was analysed by electron microprobe. Plagioclase grains within sericite-altered zones have very low calcium contents with compositions of $A n_{02-07}$. Pervasively altered tonalites locally preserve the original rock texture as pseudomorphs of fine grained mica, epidote and albite after the pre-existing plagioclase with no preferential alignment of the alteration assemblage (Figure 3c).

\subsection{Anastomosing deformation corridor}

Stone (2008a) mapped an anastomosing pattern along the western mar- 
gin of the tonalites, known as the Marmion deformation corridor (executive report by Osisko, 2013). The deformation corridor is developed in both the Marmion gneiss and in the Diversion Stock and extends up to $3 \mathrm{~km}$ away from the Finlayson Lake greenstone belt boundary (Figure 2). The deformation corridor expressed on the published maps (Stone, 2008a) includes both brittle and ductile deformation fabrics, which were not separated during mapping (Stone, personal communication).

Our observations show that the anastomosing pattern is defined by localized foliation zones that strike on average $050^{\circ}\left(035^{\circ}-075^{\circ}\right)$ with a dip of $60^{\circ}-80^{\circ}$ to the southeast (Figure 4a). Individual foliated strands range between $0.1 \mathrm{~m}$ and $5 \mathrm{~m}$ wide with a gradual decrease in the foliation intensity on either side (Figure 2). We did not identify deformation strands of $10-$ $100 \mathrm{~m}$ in width, as is shown on published maps (c.f. Stone, 2008a). The deformation intensity in foliated zones corresponds to the degree of alignment of sericite from altered feldspars (Figure 4). In cases where a significantly altered feldspar is strained, the sericite is rotated and aligned into foliationparallel sheets (Figure 4b). Aggregates of quartz are preserved as aligned boudins in the foliated sericite-rich matrix (Figure 4c). Chlorite, which typically forms a low modal proportion of the tonalites, contributes to the overall foliation intensity when chlorite-rich zones overlap with the aligned sericite. Pressure solution cleavage is observed as thin black curvilinear solution seams parallel to sericite foliation and often intersects quartz grain boundaries (Figure 4c).

We observed the foliation on outcrop to micro-scales to determine kinematics during the development of the foliation. We found no mineral lineation 
in the bulk mineral assemblage associated with the subvertical sericite foliation. Quartz shows foliation-parallel growth in pressure shadows of pyrite grains hosted in foliated sericite (Figure 8c,d). Pyrite does not record systematic rotation and we observe pressure shadows with both clockwise and anticlockwise rotation of the long axis of pyrite grains into parallelism with the foliation (Figure 8d), consistent with overall flattening. The dimensions of lithons, from sub-mm scale (Figure 4c) up to outcrop scale (Figure 2b,c), are roughly equant in the plane normal to the short axis (which trends NWSE). Each lithon is roughly symmetric around a plane normal to its short axis, which is parallel to the larger-scale foliation trend. Thus, the fabric of the anastomosing deformation corridor does not show the characteristic monoclinic symmetry often associated with shear zones (Passchier, 1998). In contrast, the symmetry and conjugate sense of rotation about the NW-SE short axis of the micro- and macro-lithons are consistent with bulk coaxial flattening (Choukroune and Gapais, 1983; Gapais et al., 1987).

The unfoliated tonalite lithons in between the foliated strands do not show any evidence of preferred sericite alignment, despite the partial to complete alteration of plagioclase to sericite (Figure 3). We measured the fracture frequency on surface exposures and along drill core approximately normal to the mean foliation (trending $\sim 320^{\circ}$ ). The lithons are fractured with a density of 10s to 100s of fractures per meter. Glacially-polished exposures of the Marmion gneiss within the Hammond Reef area, stripped during exploration activities, show two different sets of fractures in a pattern of perpendicular shear and opening-mode fractures (Figure 5). Long curviplanar shear fractures (mostly sinistral, identified from opening jogs) strike approx- 
imately NNE and have a typical spacing of $>5 \mathrm{~cm}$ (Figure 5b). Shorter open-mode fractures terminate at the intersection with the shear fractures and trend WNW with a fracture spacing of $<1 \mathrm{~cm}$ (Figure 5c). Away from stripped outcrops, weathered exposures do not allow for the classification of shear versus opening-mode fractures. Lack of exposure has not allowed us to extensively investigate this fracture set. Therefore, we documented undifferentiated fractures throughout the western margin of the study area. The undifferentiated fracture data define the same pattern of NNE and WNW trending sub-vertical fractures in the Marmion gneiss (Figure 5d). Away from the Diversion Stock contact the fracture density in the Marmion gneiss gradually decreases (Figure 2). Only the NE to NNE trending fracture group is observed in the Diversion Stock, but the pervasive WSW-striking cluster of fractures is absent (Figure 5e). Overall, the Diversion Stock shows a consistent moderate fracture density across the intrusion (see schematic representation in Figure 2b).

\subsection{Late-stage brittle faults}

Late brittle faults cross-cut the anastomosing foliation. These faults strike $030^{\circ}-060^{\circ}$ with a dip of $20^{\circ}-40^{\circ}$ to the southeast, and commonly display down-dip lineations. The slip surfaces are commonly coated with sericite, giving them a greenish sheen. These are primarily thrust faults, as evidenced by small-scale drag folding of the foliation as well as asymmetry of the smeared sericite, down-stepping in the direction of slip. This is consistent with previously reported thrust motion on shallowly southeast-dipping faults in Hammond Reef (Wasteneys, 2011).

The largest of these faults is the Lynx Head Fault (LHF), southeast of 
the Hammond Reef gold deposit (Figure 2). The fault strikes approximately $050^{\circ}$ and dips $30^{\circ}$ to the southeast (Figure 6). The Lynx Head Fault displaces unaltered hornblende-biotite tonalites with pristine feldspars to the NW over chlorite- and sericite-altered tonalites (Figure 6). The upper footwall tonalite is foliated sub-parallel to the Lynx Head Fault (Figure 6). The foliation is also defined by the alignment of sericite, similar to the anastomosing foliation described above, except for a shallower dip. The fault contains two thick fault-parallel quartz veins, separated by a few meters thick sheet of altered and intensely veined wallrock (Figure 6). Both quartz veins include blocks of altered tonalites as either centimetre-scale inclusions or as large metre-sized clasts within a mega-breccia (Figure 6), further suggesting that the Lynx Head Fault was active after the sericite-alteration of the western Marmion gneiss and Diversion Stock.

\subsection{Quartz Microstructures}

We have observed overprinting brittle and ductile deformation within the anastomosing deformation corridor. In order to further differentiate the effect of the Marmion Shear Zone in development of the damage aureole in the tonalites, we have observed quartz micro-fractures and grain boundary microstructures (Figure 7).

Quartz grain boundary morphologies are similar in the Diversion Stock and Marmion gneiss. However, they are different in unfoliated and foliated tonalite. Within unfoliated tonalite lithons, quartz grain boundaries are well preserved and show a weak bulging recrystallization (Figure 7b,c). In contrast, a moderate bulging recrystallisation with sub-grain rotation (Stipp et al., 2002; Passchier and Trouw, 2005) is observed in quartz aggregates 
within the foliated zones of the tonalites (Figure 7d,f). This is observed along quartz-quartz grain boundaries, typically along preferred orientations subparallel to foliation (Figure 8a). Rare examples of bulging recrystallization at an angle to the aligned sericite are also observed (Figure 8b). An example of a preserved feldspar within a quartz-rich zone shows brittle fracturing of the feldspar with extension perpendicular to the foliation (Figure 8a).

We compared healed micro-fractures in quartz-rich zones along the western margin of the Marmion gneiss (2 samples) with samples collected $3 \mathrm{~km}$ east of the Marmion gneiss - Diversion Stock contact (2 samples) (Figure 7g - h). Following Mitchell and Faulkner (2009), healed microfractures are interpreted from the planar alignment of fluid inclusions in quartz (see dashed lines in Figure 7). We note higher abundance of healed microfractures in the Marmion gneiss near to the Diversion stock contact (Figure 7g) than farther to the east (Figure 7h). In the Diversion Stock, all studied samples had similar density of healed microfractures (Figure 7f), at a density intermediate between the high density (proximal) and low density (distal) samples of the Marmion gneiss. We did not sample densely enough to quantify the fracture abundance trends.

\section{Deformation history}

Due to lack of exposure, overprinting retrogression in the Finlayson Lake greenstone belt and intrusion by the Diversion Stock, the early deformation history associated with the Marmion Shear Zone is not well preserved. Any kinematic reconstruction must be inferred from the deformation recorded in the adjacent terranes. In this section we focus on the deformation history of 
the Marmion gneiss and the constraints on timing and conditions of suturing with the Finlayson Lake greenstone belt. We place the observed deformation fabrics of the Marmion gneiss in the context of the deformation history from the Finlayson Lake greenstone belt (Figure 9) and discuss the possible implications for the regional tectonic history.

Ductile deformation structures observed in the Marmion gneiss include the lineation of metamorphic amphibole, folded gneissic fabrics and aligned chlorite retrogressed from amphiboles. Between the Lynx Head fault and the contact with the Diversion Stock, the hornblende in the Marmion gneiss is entirely replaced by chlorite, while hornblende is still partially preserved in the Diversion Stock. The mafic dykes that cut the Marmion gneiss (not observed in the Diversion Stock) are altered to strongly foliated chlorite and calcite. We relate the pervasive alteration in the Marmion gneiss and mafic dykes to the retrograde greenschist-facies metamorphism and foliation development along the eastern margin of the Finlayson Lake greenstone belt during $\mathrm{D}_{3}$ deformation. Prior to $\mathrm{D}_{3}$ deformation, the Finlayson Lake greenstone belt was at $21-23 \mathrm{~km}$ depth with an estimated exhumation to less than $18 \mathrm{~km}$ depth leading up to $\mathrm{D}_{3}$ deformation (Backeberg et al., 2014). We did not observe any cross-cutting relationships or clear kinematic indicators in the gneissic foliation in the Marmion gneiss to compare to the prograde $\left(D_{1}\right)$ and peak metamorphic deformation $\left(D_{2}\right)$ in the Finlayson Lake greenstone belt (Figure 9). Due to the lack of pressure-temperature constraints on the Marmion gneiss, we are unable to infer the relative displacement along the Marmion Shear Zone. The Marmion Shear Zone is a steeply eastwarddipping structure (Backeberg et al., 2014). The terrane boundaries cut by 
the Marmion Shear are not restorable in map view (Figure 1), so the displacement likely had a vertical component even if the shear zone accommodated mostly strike-slip as previously inferred (Stone et al., 1992; Stone, 2010).

The Diversion Stock then intrudes the chlorite foliation of the Finlayson Lake greenstone belt (Backeberg et al., 2014), crosscutting $\mathrm{D}_{3}$ fabrics and greenschist-facies assemblage (Figure 9), consistent with the lack of quartzductile deformation in the Diversion Stock. No textural evidence of map-scale simple shear has been observed in the $\mathrm{D}_{3}$ fabrics in either terrane (see also Backeberg et al., 2014). All deformation fabrics during and after $\mathrm{D}_{3}$ record NW shortening in both the Finlayson Lake greenstone belt (Backeberg et al., 2014) and in the Marmion gneiss (this study), perpendicular to the Marmion Shear Zone. The regional NW-SE shortening axis is not favourable for slip in any orientation along the Marmion Shear Zone. Therefore, the suturing of the terranes and the emplacement of the Diversion Stock also imply the end of any major offset along the Marmion Shear Zone, thus making the shear zone effectively dormant.

All post $\mathrm{D}_{3}$ quartz-brittle deformation fabrics in both the Diversion Stock and the Marmion gneiss are consistent with coaxial NW-SE shortening perpendicular to the contact with the Finlayson Lake greenstone belt. We subdivide the $\mathrm{D}_{4}$ structures in the Marmion gneiss into distributed deformation $\left(\mathrm{D}_{4 a}\right.$ and $\left.\mathrm{D}_{4 b}\right)$ and localized faulting $\left(\mathrm{D}_{4 c}\right)$.

A pattern of perpendicular shear and open-mode fractures was observed at Hammond Reef $\left(\mathrm{D}_{4 a}\right.$; Figures 5, 9). We suggest that the fracture sets provided the initial permeability for fluids to migrate through the tonalites. The Marmion gneiss may have a longer history of fracturing that began be- 
fore the emplacement of the Diversion Stock (as suggested by the qualitative comparison of the abundance of healed microfractures; Figure 5f-h). Alteration of plagioclase to sericite is concentrated along $\mathrm{D}_{4 a}$ fractures (Figure 3a). Locally the sericite is aligned into anastomosing foliation strands $\left(\mathrm{D}_{4 b}\right.$; Figure 9), which we discuss in detail in the following section.

Shallowly SE-dipping thrust faults (e.g. the Lynx Head Fault) cross-cut the sericite-altered tonalites and the anastomosing foliation. These faults record a change from distributed deformation $\left(\mathrm{D}_{4 a, b}\right)$ to localized faulting $\left(\mathrm{D}_{4 c}\right)$, while the NW-SE shortening axis was maintained (Figure 9). At the Lynx Head Fault, we observed sericite foliation in the footwall parallel to the fault surface (Figure 6). As sericite tonalites are inherently weaker due to the higher modal proportion of phyllosilicates, we interpret this shallower foliation as drag and alignment of sericite related to slip coeval with $\mathrm{D}_{4 c}$ thrust faulting (Figure 9).

\section{Deformation adjacent to a dormant shear zone}

The structures and fabrics in the Marmion gneiss reveal overprinting stages of the late shallow deformation $\left(\mathrm{D}_{3}-\mathrm{D}_{4}\right)$ in a damage aureole in close proximity to the Marmion Shear Zone. Combined with the details of early ductile stages of deformation preserved in the adjacent Finlayson Lake greenstone belt (Backeberg et al., 2014), these results describe a continuous regional deformation path that spans the suturing of the two terranes and ongoing post-suturing fluid activity and deformation. In this section we discuss the implications of the late-stage deformation adjacent to an effectively kinematically dormant shear zone. 


\subsection{Fault- or intrusion-related damage?}

In the Finlayson Lake greenstone belt, late-stage brittle fracturing is localized within $<100 \mathrm{~m}$ of the eastern boundary and slip is recorded predominantly by offset veins and steep slickenlines on surfaces of the penetrative planar foliation in chlorite schists (Backeberg et al., 2014). In the Marmion gneiss and the Diversion Stock tonalites there were no through-going preexisting structures with the potential for reactivation during $\mathrm{D}_{4}$. In this section we consider the fracture development within the context of shear activity of the Marmion Shear Zone relative to the timing of emplacement of the Diversion Stock.

General observations of a decreasing fracture density in the Marmion gneiss $\sim 1.5 \mathrm{~km}$ southeast of the Marmion-Diversion contact (Figure $2 \mathrm{~b}$ ) are comparable with documented brittle damage zones (Chester and Logan, 1986; Chester et al., 2004; Mitchell and Faulkner, 2009; Faulkner et al., 2010; Savage and Brodsky, 2011). The relatively wider damage zone in the tonalites compared to the adjacent greenstone belt is consistent with damage zone asymmetries noted around faults, which juxtapose different lithologies (e.g. Evans, 1990; Chester et al., 2005; Mitchell et al., 2011; Savage and Brodsky, 2011). The qualitatively observed decreasing fracture density in the Marmion gneiss with distance east of the Diversion Stock (Figure 7g and h) may represent the older damage zone in the Marmion gneiss, which was displaced by the intrusion of the Diversion Stock.

However, fracture densities in the Diversion Stock are still high, above the density of fractures in distal samples from the Marmion gneiss. The Diversion Stock is not offset or deformed by any map-scale faults, precluding any major 
offset along the Marmion Shear Zone after emplacement (Figure 7f). Considering an effectively locked Marmion Shear Zone during post- $\mathrm{D}_{3}$ deformation, it is necessary to consider other features that may have contributed to postshearing fracturing in the Diversion Stock and pervasive sericite alteration in both the Marmion gneiss and Diversion Stock. Any deformation after emplacement of the Diversion Stock can only have been related to the intrusion and cooling of the intrusion, exhumation, fluid pulses, and/or small-scale slip along the two intrusive contacts either side of the Diversion Stock. Intrusionderived fluids have been shown to promote fracturing of the intrusive body itself as well as the country rock (Essaifi et al., 2004; Pollard et al., 2005). In such a model, the intrusion of the Diversion Stock could have provided the fluids during exhumation required for fracturing of the Marmion gneiss (the country rock) as well as fracturing of the cooling Diversion Stock itself (the intrusive body).

\subsection{Fluid flow, alteration, and foliation development}

Both ductile and brittle microstructures (Section 3.7) suggest that a real damage zone (in the sense of Chester and Logan, 1986; Cowie and Shipton, 1998; Childs et al., 2009; Faulkner et al., 2010; Savage and Brodsky, 2011, and others) existed along the western edge of the Marmion gneiss prior to the intrusion of the Diversion Stock. Cross-cutting relations and our reconstruction of the metamorphic history of the neighboring terrane (Backeberg et al., 2014) indicate that the influence of deformation along the Marmion Shear ended after the transition from quartz-ductile, plagioclase-brittle flow (Figure 8) and gave way to pervasive fluid flow along microfractures (Figure 5 ) in both the Diversion Stock and the Marmion gneiss. The alteration of 
felspar to sericite initiated along microfractures and grain boundaries. The nearly complete alteration of feldspar within the damage aureole implies that the alteration reaction did not result in sealing of the grain boundaries.

Sericitized zones are locally flattened (Figure 4) and on the map-scale form a discontinuous anastomosing network (Figure 2). On the grain-scale, we observe a pattern that is defined by the alignment of sericite around undeformed quartz aggregates (microlithons), which is comparable to the definition of a continuous "rough" cleavage (Gray, 1978; Fossen, 2010). At outcrop- and map-scale we observe no major offset across foliation zones and the NW-SE shortening is accommodated by overall flattening without any major simple shear component (Figure 4a). This is consistent with the rotation of the long axis of pyrite grains hosted in foliated sercite matrix parallel to the mean foliation (Figure 4e,f). Anastomosing deformation networks are typically associated with simple or general shear, not with pure shear (flattening) (e.g. Carreras et al., 2010; Ponce et al., 2010). However, in the case of the deformation in the tonalites adjacent to the Marmion Shear Zone, the dominant mineralogy defining the anastomosing fabric postdates the cessation of motion on the Marmion Shear and records predominantly flattening perpendicular to the shear zone. The geometry and kinematics we observe with the micro- and macro-lithons of the Marmion damage aureole and comparable to coaxial flattening shear zone networks (Choukroune and Gapais, 1983; Gapais et al., 1987).

Grain-scale textures in partially altered plagioclase (Figure $4 \mathrm{~b}$ ) suggest that flattening is at least in part coeval with sericite replacing feldspars. Therefore, we interpret that the foliation recorded a decreasing yield strength 
of the tonalites, driven by progressive alteration of plagioclase to weaker sericite. Reaction-weakening in the cores of shear zones has been shown to localize ductile shearing (e.g. Cox, 2002), so by analogy, we suggest a similar process resulted in the anastomosing foliation zone. Flattening occurred where the modal proportion of sericite became high enough to form interlinking rough cleavage. For the most part, we observe bulging recrystallization and sub-grain rotation along quartz grain boundaries together with the anastomosing foliation in both the Marmion gneiss and the Diversion Stock (Figure $7 \mathrm{~b}-\mathrm{e})$. Bulging recrystallization with sub-grain rotation is comparable with experimental textures from low temperature deformation at $300-400^{\circ} \mathrm{C}$ (Hirth and Tullis, 1992; Stipp et al., 2002). These temperatures are consistent with the predicted exhumation path of the Finlayson Lake greenstone belt, which constrains $\mathrm{D}_{4}$ structures below $\sim 500^{\circ} \mathrm{C}$, after the emplacement of the Diversion Stock (Backeberg et al., 2014). The stronger bulging recrystallisation in foliation zones (Figure $7 \mathrm{~d}-\mathrm{e}$ ) could be a response of localized higher strain during flattening and formed coeval with flattening. Alternatively, the crystal plastic deformation may be a precursor fabric that initiated the map-scale anastomosing network and was preferentially flattened during alteration. Preserved grain boundary recrystallization in quartz microlithons is sometimes developed at an angle to the foliation (Figure 8b), suggesting that it may be an older fabric. All kinematic indicators observed during $\mathrm{D}_{4}$ deformation record NW-SE shortening perpendicular to the boundary with the Finlayson Lake greenstone belt and the dormant Marmion Shear Zone. 


\section{Linking the deformation to a regional tectonic setting}

The deformation history of the Marmion gneiss is summarized in Figure

9 together with the deformation history of the Finlayson Lake greenstone belt (Backeberg et al., 2014). Backeberg et al. (2014) postulated the $\mathrm{D}_{4}$ structural event observed in the greenstone belt was related to the smallscale reactivation of the Marmion Shear Zone during the amalgamation of the Wawa, Quetico and Wabigoon subprovinces with dextral transpression along the Quetico Fault estimated at $\sim 2.70$ Ga (Percival, 1989; Williams, 1990). Our observations reported here, specifically the cessation of motion on the Marmion Shear Zone after the intrusion of the Diversion Stock, imply that no significant reactivation occurred. Dextral transpression across the Quetico Fault is consistent with an approximate NW-SE horizontal shortening axis recorded in structural fabrics, which we interpret for structures in the Marmion gneiss and Diversion Stock. The age of the Diversion Stock, which marks the lower limit of shear zone activity, is not known. The timing has been tentatively linked to a similar intrusive body dated to $\sim 2.786 \mathrm{Ga}$, which lies to the north of the Marmion gneiss (Buse et al., 2010). Therefore, the terrane boundary and Marmion Shear Zone experienced a quiescent period that lasted in the order of 80 million years prior to reactivation associated with localized alteration-weakening and the development of the anastomosing foliation in the damage aureole.

\section{Conclusion}

The damage aureole adjacent to the Marmion Shear Zone has a long lived history, longer than that of the shear zone itself. While the shear zone was 
active, ductile fabrics developed in both the Finlayson Lake greenstone belt and the juxtaposed Marmion gneiss terrane, as well as distributed microfractures that may represent the damage zone formed during the latest (brittle) stage of activity. This was followed by stitching of the two terranes and "locking" of the shear zone during the emplacement and cooling of the Diversion Stock. Post-intrusive microfracturing, fluid flow and alteration led to the replacement of feldspar by sericite and preferential flattening in an anastomosing foliation network. The map-scale controls on the anastomosing geometry are not well understood, but microstructures suggest that it may have been directed by a weak foliation geometry inherited from the ductile fabrics of the Marmion Shear Zone.

The NW-SE, sub-horizontal shortening recorded by flattening and thrust faulting after the locking of the Marmion Shear Zone is kinematically consistent with dextral transpression on the $\sim 2.70$ Ga Quetico Fault during the amalgamation of the Superior Province.

\section{Acknowledgments}

This project was funded by Osisko Exploration Ltd. and the Natural Sciences and Engineering Research Council of Canada through a Collaborative Research and Development grant to Christie Rowe. Osisko provided us with field logistics and ongoing support throughout the study. This manuscript was greatly improved by comments and suggestions by Yvette Kuiper, Giorgio Pennacchioni, Mary Louise Hill and the editor, Joao Hippertt. A special thank you is due to Robert Wares, Anne Charland, Denver Stone, Jami Brown, Denis Villeneuve, Zoran Madon and many other Osisko employees 
for their discussions, interest and support. Thanks to Katarina Bjorkman and her family for field support and local knowledge about outcrops and gold showings. We would like to thank Vincent van Hinsberg, Ben Melosh and Eric Bellefroid for further assistance and discussions on various topics in this paper.

\section{References}

Arancibia, G., Fujita, K., Hoshino, K., Mitchell, T. M., Cembrano, J., Gomila, R., Morata, D., Faulkner, D. R., Rempe, M., 2014. Hydrothermal alteration in an exhumed crustal fault zone: Testing geochemical mobility in the Caleta Coloso Fault, Atacama Fault System, Northern Chile. Tectonophysics 623, 147-168.

Backeberg, N. R., Rowe, C. D., van Hinsberg, V. J., Bellefroid, E. J., 2014. Structural and metamorphic evidence for Mesoarchaean subduction in the Finlayson Lake greenstone belt, Superior Province, Ontario. Precambrian Research 249, 100-114.

Bauer, R. L., Hudleston, P. J., Southwick, D. L., 1992. Deformation across the western Quetico subprovince and adjacent boundary regions in Minnesota. Canadian Journal of Earth Sciences 29 (10), 2087-2103.

Bezerra, F. H. R., Rossetti, D. F., Oliveira, R. G., Medeiros, W. E., Neves, B. B. B., Balsamo, F., Nogueira, F. C. C., Dantas, E. L., Andrades Filho, C., Góes, A. M., 2014. Neotectonic reactivation of shear zones and implications for faulting style and geometry in the continental margin of NE Brazil. Tectonophysics 614, 78-90. 
Bjorkman, K. E., Lu, Y., McCuaig, T. C., Hollings, P., Beakhouse, G. P., 2015. Linking crustal evolution to mineral systems using U-Pb geochronology in zircons from the Marmion Terrane (3.02-2.68 Ga), western Superior Craton, Canada. In: Vanderhaeghe, O., Baratoux, L., McCuaig, T. C. (Eds.), 13th Biennial Meeting, Society for Geology Applied to Mineral Deposits. Nancy, France.

Buse, S., Lewis, D., Davis, D. W., Hamilton, M. A., 2010. U/Pb Geochronological Results from the Lumby Lake Greenstone Belt, Wabigoon Subprovince, Northwestern Ontario. Tech. Rep. Project Unit 09-007, Ontario Geological Survey.

Caine, J. S., Bruhn, R. L., Forster, C. B., 2010. Internal structure, fault rocks, and inferences regarding deformation, fluid flow, and mineralization in the seismogenic Stillwater normal fault, Dixie Valley, Nevada. Journal of Structural Geology 32 (11), 1576-1589.

Caine, J. S., Evans, J. P., Forster, C. B., 1996. Fault zone architecture and permeability structure. Geology 24 (11), 1025-1028.

Calvert, A. J., Sawyer, E. W., Davis, W. J., Ludden, J. N., 1995. Archean subduction inferred from seismic images of a mantle suture in the Superior Province. Nature 375, 670-674.

Carreras, J., Czeck, D. M., Druguet, E., Hudleston, P. J., 2010. Structure and development of an anastomosing network of ductile shear zones. Journal of Structural Geology 32 (5), 656-666. 
Chester, F. M., Chester, J. S., 1998. Ultracataclasite structure and friction processes of the Punchbowl fault, San Andreas system, California. Tectonophysics 295 (1), 199-221.

Chester, F. M., Chester, J. S., Kirschner, D. L., Schulz, S. E., Evans, J. P., 2004. Structure of large-displacement, strike-slip fault zones in the brittle continental crust. Rheology and Deformation in the Lithosphere at Continental Margins 1, 223-260.

Chester, F. M., Logan, J. M., 1986. Implications for mechanical properties of brittle faults from observations of the Punchbowl fault zone, California. Pure and Applied Geophysics 124 (1-2), 79-106.

Chester, J. S., Chester, F. M., Kronenberg, A. K., 2005. Fracture surface energy of the Punchbowl fault, San Andreas system. Nature 437 (7055), $133-136$.

Childs, C., Manzocchi, T., Walsh, J. J., Bonson, C. G., Nicol, A., Schöpfer, M. P. J., 2009. A geometric model of fault zone and fault rock thickness variations. Journal of Structural Geology 31 (2), 117-127.

Choukroune, P., Gapais, D., 1983. Strain pattern in the Aar Granite (Central Alps): orthogneiss developed by bulk inhomogeneous flattening. Journal of Structural Geology 5 (3-4), 411-418.

Clark, C., Mumm, A. S., Faure, K., 2005. Timing and nature of fluid flow and alteration during Mesoproterozoic shear zone formation, Olary Domain, South Australia. Journal of Metamorphic Geology 23 (3), 147-164. 
Corfu, F., Stott, G. M., 1986. U-Pb ages for late magmatism and regional deformation in the Shebandowan Belt, Superior Province, Canada. Canadian Journal of Earth Sciences 23, 1075-1082.

Coward, M. P., 1976. Strain within ductile shear zones. Tectonophysics 34 (3), 181-197.

Cowie, P. A., Shipton, Z. K., 1998. Fault tip displacement gradients and process zone dimensions. Journal of Structural Geology 20 (8), 983-997.

Cox, S. F., 2002. Fluid flow in mid-to deep crustal shear systems: Experimental constraints, observations on exhumed high fluid flux shear systems, and implications for seismogenic processes. Earth, planets and space 54 (11), $1121-1125$.

Davis, D. W., Jackson, M. C., 1988. Geochronology of the Lumby Lake greenstone belt: A 3 Ga complex within the Wabigoon subprovince, northwest Ontario. Geological Society of America Bulletin 100, 818-824.

Essaifi, A., Capdevila, R., Fourcade, S., Lagarde, J. L., Ballvère, M., Marignac, C. H., 2004. Hydrothermal alteration, fluid flow and volume change in shear zones: the layered mafic-ultramafic Kettara intrusion (Jebilet Massif, Variscan belt, Morocco). Journal of Metamorphic Geology 22, 25-43.

Evans, J. P., 1990. Thickness-displacement relationships for fault zones. Journal of Structural Geology 12 (8), 1061-1065.

Faulkner, D. R., Jackson, C. A. L., Lunn, R. J., Schlische, R. W., Shipton, Z. K., Wibberley, C. A. J., Withjack, M. O., 2010. A review of recent 
developments concerning the structure, mechanics and fluid flow properties of fault zones. Journal of Structural Geology 32 (11), 1557-1575.

Faulkner, D. R., Lewis, A. C., Rutter, E. H., 2003. On the internal structure and mechanics of large strike-slip fault zones: Field observations of the Carboneras fault in southeastern Spain. Tectonophysics 367 (3), 235-251.

Fossen, H., 2010. Structural Geology. Cambridge University Press, Cambridge, U.K.

Fusseis, F., Handy, M. R., Schrank, C., 2006. Networking of shear zones at the brittle-to-viscous transition (Cap de Creus, NE Spain). Journal of Structural Geology 28 (7), 1228-1243.

Gapais, D., Bale, P., Choukroune, P., Cobbold, P., Mahjoub, Y., Marquer, D., 1987. Bulk kinematics from shear zone patterns: some field examples. Journal of Structural Geology 9 (5-6), 635-646.

Goddard, J. V., Evans, J. P., 1995. Chemical changes and fluid-rock interaction in faults of crystalline thrust sheets, northwestern Wyoming, USA. Journal of Structural Geology 17 (4), 533-547.

Gray, D. R., 1978. Cleavages in deformed psammitic rocks from southeastern Australia: their nature and origin. Geological Society of America Bulletin 89 (4), 577-590.

Gudmundsson, A., Berg, S. S., Lyslo, K. B., Skurtveit, E., 2001. Fracture networks and fluid transport in active fault zones. Journal of Structural Geology 23 (2), 343-353. 
Hirth, G., Tullis, J., 1992. Dislocation creep regimes in quartz aggregates. Journal of Structural Geology 14 (2), 145-159.

Holdsworth, R. E., Stewart, M., Imber, J., Strachan, R. A., 2001. The structure and rheological evolution of reactivated continental fault zones: a review and case study. Geological Society, London, Special Publications 184 (1), 115-137.

Johri, M., Dunham, E. M., Zoback, M. D., Fang, Z., 2014. Predicting fault damage zones by modeling dynamic rupture propagation and comparison with field observations. Journal of Geophysical Research: Solid Earth 119 (2), 1251-1272.

Kennedy, B. M., Kharaka, Y. K., Evans, W. C., Ellwood, A., DePaolo, D. J., Thordsen, J., Ambats, G., Mariner, R. H., 1997. Mantle fluids in the San Andreas fault system, California. Science 278 (5341), 1278-1281.

Kim, Y.-S., Peacock, D. C. P., Sanderson, D. J., 2004. Fault damage zones. Journal of Structural Geology 26 (3), 503-517.

Kulongoski, J. T., Hilton, D. R., Barry, P. H., Esser, B. K., Hillegonds, D., Belitz, K., 2013. Volatile fluxes through the Big Bend section of the San Andreas Fault, California: Helium and carbon-dioxide systematics. Chemical Geology 339, 92-102.

Micklethwaite, S., 2009. Mechanisms of faulting and permeability enhancement during epithermal mineralisation: Cracow goldfield, Australia. Journal of Structural Geology 31 (3), 288-300. 
Mitchell, T. M., Ben-Zion, Y., Shimamoto, T., 2011. Pulverized fault rocks and damage asymmetry along the Arima-Takatsuki Tectonic Line, Japan. Earth and Planetary Science Letters 308 (3), 284-297.

Mitchell, T. M., Faulkner, D. R., 2009. The nature and origin of off-fault damage surrounding strike-slip fault zones with a wide range of displacements: A field study from the Atacama fault system, northern Chile. Journal of Structural Geology 31 (8), 802-816.

Mohanty, S., Ramsay, J. G., 1994. Strain partitioning in ductile shear zones: an example from a Lower Pennine nappe of Switzerland. Journal of Structural Geology 16 (5), 663-676.

Moir, H., Lunn, R. J., Micklethwaite, S., Shipton, Z. K., 2013. Distant offfault damage and gold mineralization: The impact of rock heterogeneity. Tectonophysics 608, 461-467.

Morton, N., Girty, G. H., Rockwell, T. K., 2012. Fault zone architecture of the San Jacinto fault zone in Horse Canyon, southern California: A model for focused post-seismic fluid flow and heat transfer in the shallow crust. Earth and Planetary Science Letters 329, 71-83.

Musacchio, G., White, D. J., Asudeh, I., Thomson, C. J., 2004. Lithospheric structure and composition of the Archean western Superior Province from seismic refraction/wide-angle reflection and gravity modeling. Journal of Geophysical Research: Solid Earth (1978-2012) 109.

Osisko, December 2013. Executive summary: Hammond Reef gold project, Unpublished internal report. 
Passchier, C. W., 1998. Monoclinic model shear zones. Journal of Structural Geology 20 (8), 1121-1137.

Passchier, C. W., Trouw, R. A. J., 2005. Microtectonics, 2nd Edition. Springer.

Percival, J. A., 1989. A regional perspective of the Quetico metasedimentary belt, Superior Province, Canada. Canadian Journal of Earth Sciences $26(4), 677-693$.

Percival, J. A., 2007. Eo- to Mesoarchean terranes of the Superior Province and their tectonic context. In: Van Kranendonk, M. J., Smithies, R. H., Bennet, V. C. (Eds.), Earth's Oldest Rocks. Vol. 15, Developments in Precambrian Geology. pp. 1065-1085.

Percival, J. A., Sanborn-Barrie, M., Skulski, T., Stott, G. M., Helmstaedt, H., White, D. J., 2006. Tectonic evolution of the western Superior Province from NATMAP and Lithoprobe studies. Canadian Journal of Earth Sciences $43,1085-1117$.

Percival, J. A., Williams, H. R., 1989. Late Archean Quetico accretionary complex, Superior province, Canada. Geology 17 (1), 23-25.

Peterson, V. L., Zaleski, E., 1999. Structural history of the Manitouwadge greenstone belt and its volcanogenic $\mathrm{Cu}-\mathrm{Zn}$ massive sulphide deposits, Wawa subprovince, south-central Superior Province. Canadian Journal of Earth Sciences 36 (4), 605-625.

Piessens, K., Muchez, P., Dewaele, S., Boyce, A., De Vos, W., Sintubin, M., Debacker, T. N., Burke, E. A. J., Viaene, W., 2002. Fluid flow, alteration 
and polysulphide mineralisation associated with a low-angle reverse shear zone in the Lower Palaeozoic of the Anglo-Brabant fold belt, Belgium. Tectonophysics 348 (1), 73-92.

Polat, A., Kerrich, R., 2001. Geodynamic processes, continental growth, and mantle evolution recorded in late Archean greenstone belts of the southern Superior Province, Canada. Precambrian Research 112 (1), 5-25.

Pollard, P. J., Taylor, R. G., Peters, L., 2005. Ages of intrusion, alteration, and mineralization at the Grasberg $\mathrm{Cu}-\mathrm{Au}$ deposit, Papua, Indonesia. Economic Geology 100 (5), 1005-1020.

Ponce, C., Carreras, J., Druguet, E., 2010. Development of "lozenges" in anastomosing shear zone networks in foliated rocks. Geologia Estructural y Tectónica 48, 207-210.

Ramsay, J. G., 1980. Shear zone geometry: a review. Journal of structural geology 2 (1), 83-99.

Rawling, G. C., Goodwin, L. B., Wilson, J. L., 2001. Internal architecture, permeability structure, and hydrologic significance of contrasting faultzone types. Geology 29 (1), 43-46.

Rutter, E. H., Holdsworth, R. E., Knipe, R. J., 2001. The nature and tectonic significance of fault-zone weakening: an introduction. Geological Society, London, Special Publications 186 (1), 1-11.

Salomon, E., Koehn, D., Passchier, C. W., 2015. Brittle reactivation of ductile shear zones in NW Namibia in relation to South Atlantic rifting. Tectonics 34 (1), 70-85. 
Savage, H. M., Brodsky, E. E., 2011. Collateral damage: Evolution with displacement of fracture distribution and secondary fault strands in fault damage zones. Journal of Geophysical Research: Solid Earth (1978-2012) 116 (B3), 1-14.

Shipton, Z. K., Cowie, P. A., 2003. A conceptual model for the origin of fault damage zone structures in high-porosity sandstone. Journal of Structural Geology 25 (3), 333-344.

Sibson, R. H., 1992. Implications of fault-valve behaviour for rupture nucleation and recurrence. Tectonophysics 211 (1), 283-293.

Sibson, R. H., 2001. Seismogenic framework for hydrothermal transport and ore deposition. Reviews in Economic Geology 14, 25-50.

Sibson, R. H., 2003. Thickness of the seismic slip zone. Bulletin of the Seismological Society of America 93 (3), 1169-1178.

Sibson, R. H., Robert, F., Poulsen, K. H., 1988. High-angle reverse faults, fluid-pressure cycling, and mesothermal gold-quartz deposits. Geology $16(6), 551-555$.

Stipp, M., Stünitz, H., Heilbronner, R., Schmid, S. M., 2002. The eastern Tonale fault zone: A 'natural laboratory' for crystal plastic deformation of quartz over a temperature range from 250 to $700{ }^{\circ} \mathrm{C}$. Journal of Structural Geology 24 (12), 1861-1884.

Stone, D., 2008a. Precambrian geology, Atikokan Area, Preliminary Map P.3349-Revised. Tech. rep., Ontario Geological Survey. 
Stone, D., 2008b. Precambrian geology, Sapawe Area, Preliminary Map P.3350-Revised. Tech. rep., Ontario Geological Survey.

Stone, D., 2010. Precambrian geology of the central Wabigoon subprovince area, northwest Ontario. Tech. Rep. Open File Report 5422, Ontario Geological Survey.

Stone, D., Kamineni, D. C., Jackson, M. C., 1992. Precambrian geology of the Atikokan Area, northwestern Ontario. Tech. Rep. Bulletin 405, Geological Survey of Canada.

Tomlinson, K. Y., Davis, D. W., Stone, D., Hart, T. R., 2003. U-Pb age and $\mathrm{Nd}$ isotopic evidence for Archean terrane development and crustal recycling in the south-central Wabigoon subprovince, Canada. Contributions to Mineralogy and Petrology 144, 684-702.

Tomlinson, K. Y., Hughes, D. J., Thurston, P. C., Hall, R. P., 1999. Plume magmatism and crustal growth at 2.9 to $3.0 \mathrm{Ga}$ in the Steep Rock and Lumby Lake area, Western Superior Province. Lithos 46, 103-136.

Tomlinson, K. Y., Stone, D., Hattori, K. H., 2004. Basement terranes and crustal recycling in the western Superior Province: Nd isotopic character of granitoid and felsic volcanic rocks in the Wabigoon subprovince, N. Ontario, Canada. Precambrian Research 132, 245-274.

Vearncombe, J. R., 1998. Shear zones, fault networks, and Archean gold. Geology 26 (9), 855-858.

Wasteneys, H., 2011. Report on Kabakong, Lynx Head Bay and Snail Bay 
Table 1: Comparative description of the Diversion Stock and the Marmion gneiss. Mineralogy abbreviations correspond to quartz (Qtz), feldspar (Fsp), plagioclase (Pl), microcline (Mc), hornblende ( $\mathrm{Hbl})$, biotite $(\mathrm{Bt})$, muscovite $(\mathrm{Ms})$ and chlorite $(\mathrm{Chl})$. *Buse et al. $\underline{(2010) * * \text { Stone }(2010)}$

\begin{tabular}{l|l|l}
\hline & Diversion Stock & Marmion gneiss \\
\hline Rock types & tonalite - granodiorite & tonalite gneiss \\
Age $(\mathrm{Ma})$ & $?(2786 \pm 1, \text { correlated })^{*}$ & $3002 \pm 3^{* *}$ \\
Primary Mineralogy & Qtz, Pl, Mc, Hbl, Ms & Qtz, Pl, Hbl, Bt \\
Outcrop characteristic & Qtz coarser than Fsp & Qtz finer than Fsp \\
& higher modal Qtz & higher modal Hbl (or Chl) \\
Fabrics & none & aligned Hbl and foliated Chl \\
Chlorite alteration & weak & pervasive \\
Sericite alteration & pervasive, locally aligned & pervasive, locally aligned
\end{tabular}

Map Areas for Osisko Hammond Reef Gold Inc. Tech. rep., Hammond Reef Geological Mapping Programme 2010.

Williams, H. R., 1990. Subprovince accretion tectonics in the south-central Superior Province. Canadian Journal of Earth Sciences 27 (4), 570-581. 


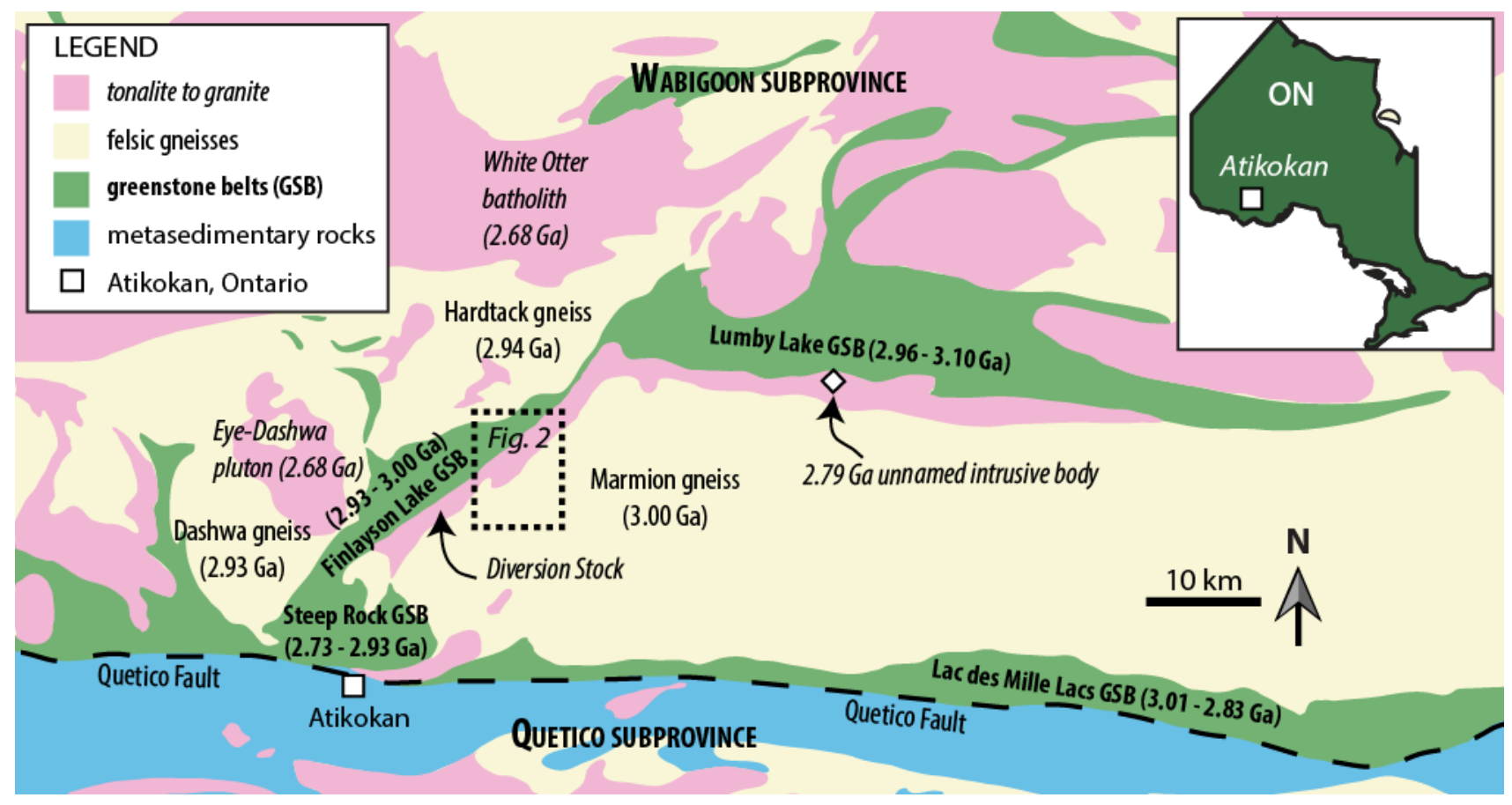

Figure 1: A simplified regional geological map of the south-central Wabigoon subprovince showing the ages of the Archean tonalite-trodhjemite-granodiorite (TTG) and greenstone belt terranes (modified from Stone, 2008a). The eastern boundary of the Finlayson Lake greenstone belt with the Marmion gneiss is thought to be a tectonic contact called the Marmion Shear Zone, and was intruded by the Diversion Stock. The east-west trending dextral Quetico fault to the south separates the Wabigoon subprovince (north) from the Quetico subprovince (south). Location of $\mathrm{U}-\mathrm{Pb}$ age for boundary intrusive between Marmion gneiss and Lumby Lake greenstone belt is shown (diamond, Buse et al., 2010). Inset map: Outline of Ontario, Canada with location of Atikokan shown. 

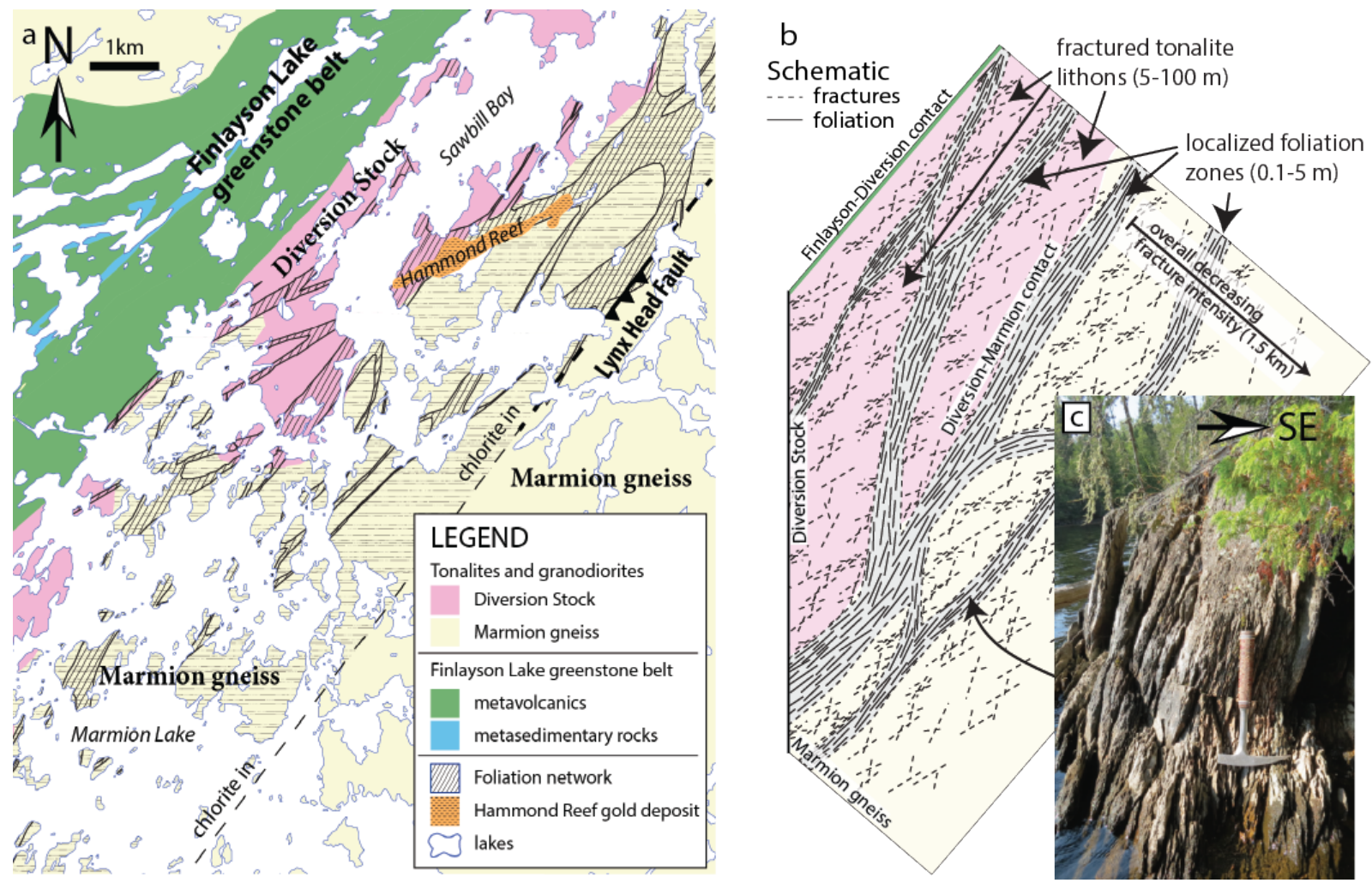

Figure 2: (a) Map of Marmion-Finlayson terrane boundary and anastomosing foliation zones across the Diversion Stock tonalite - granodiorite and Marmion tonalite gneiss (adapted from Stone (2008a)). Lithological contacts are only mapped along lake-shore exposures, elsewhere they are inferred. Southeastward extent of chlorite in the Marmion gneiss is shown by the dashed "chlorite in" line, which trends towards known exposures of the Lynx Head Fault (LHF). (b) Schematic map of anastomosing foliation (not to scale), showing localized foliation zones (solid lines in grey-shaded area) and inter-foliation lithons with fractures (dashed lines). Decreasing fracture density in Marmion gneiss is shown schematically. (c) Photograph of a foliated tonalite. 

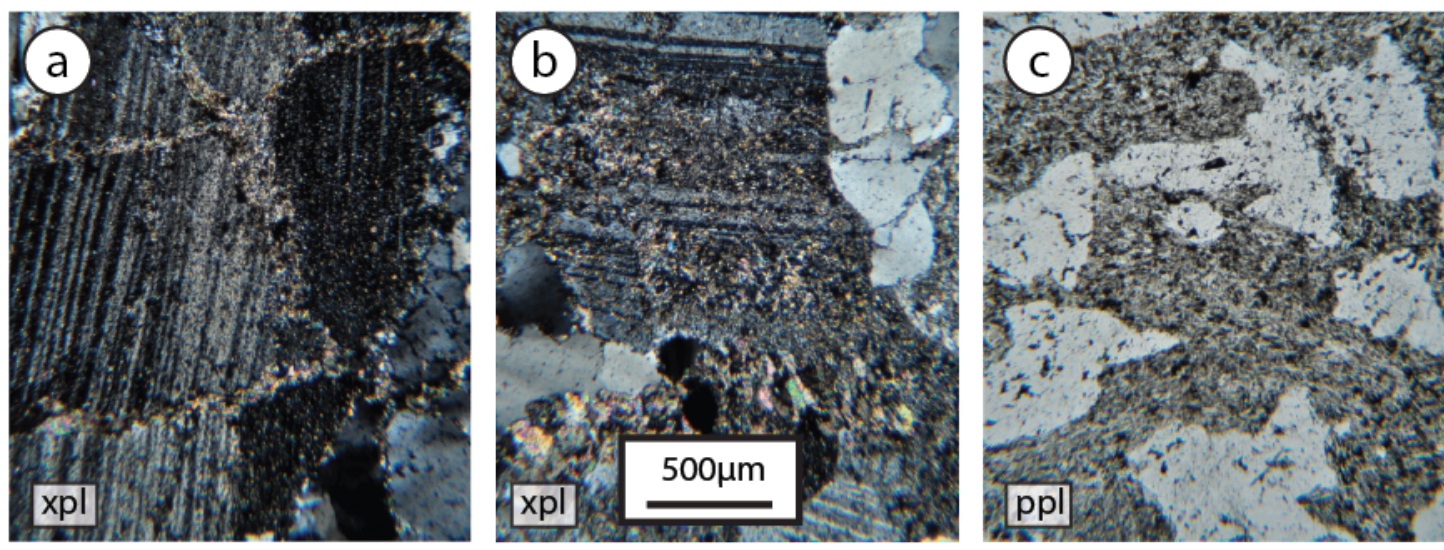

(d)
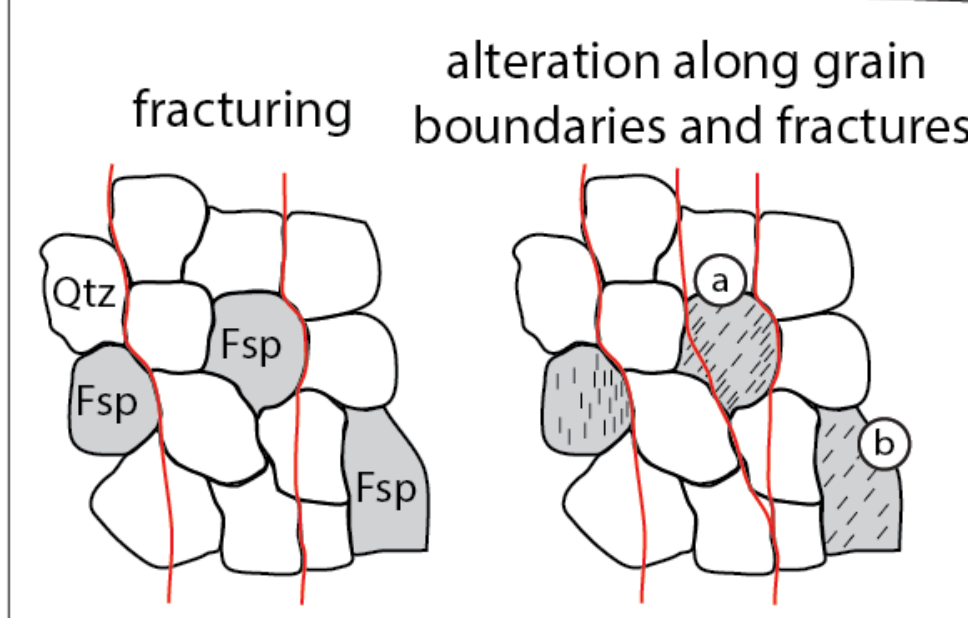

static alteration

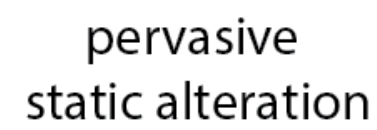

Figure 3: Representative photos (a-b: cross-polarized light (xpl) and c: plain polarized light (PPL)) and schematic of variations in intensity of sericite alteration in tonalites throughout the Marmion gneiss and Diversion Stock (see text for details). (a) Fracture and grain-boundary localized sericite alteration. (b) Partially sericite-altered plagioclase. (c) Pervasive sericite alteration preserving plagioclase pseudomorphs without strain. (d) Schematic simplified to represent only quartz (Qtz) and feldspar (grey-shaded, Fsp) with secondary sericite (hash marks). Red lines indicate fluid pathways in fractures or along grain boundaries. 


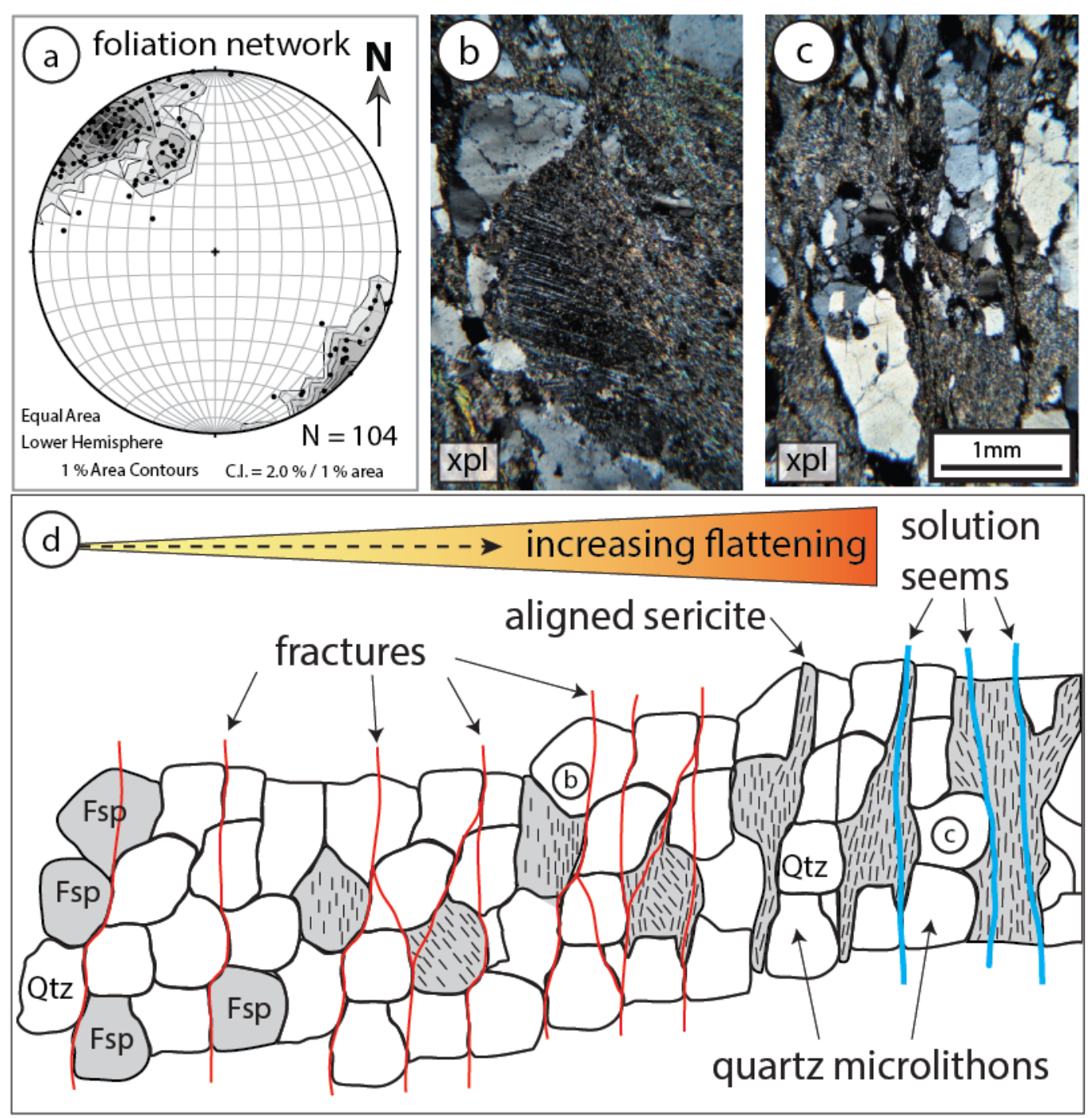

Figure 4: Progressive alignment of sericite from altered feldspars (plagioclase and orthoclase) during flattening, which forms the foliation in foliated tonalites. Colors are as in Figure 3, blue lines are solution seams. (a) Equal-area lower-hemisphere projection showing poles to foliation plane orientations indicating a general steeply SE-dipping orientation. (b, c) Partially altered feldspars show alignment of sericite parallel to foliation, concentrated along fractures. (d) Pervasively altered tonalites preserve no feldspar pseudomorphs and the aligned sericite defines the foliation. Fractured quartz microlithons and spaced solution seems (blue lines) are aligned parallel to foliation. 

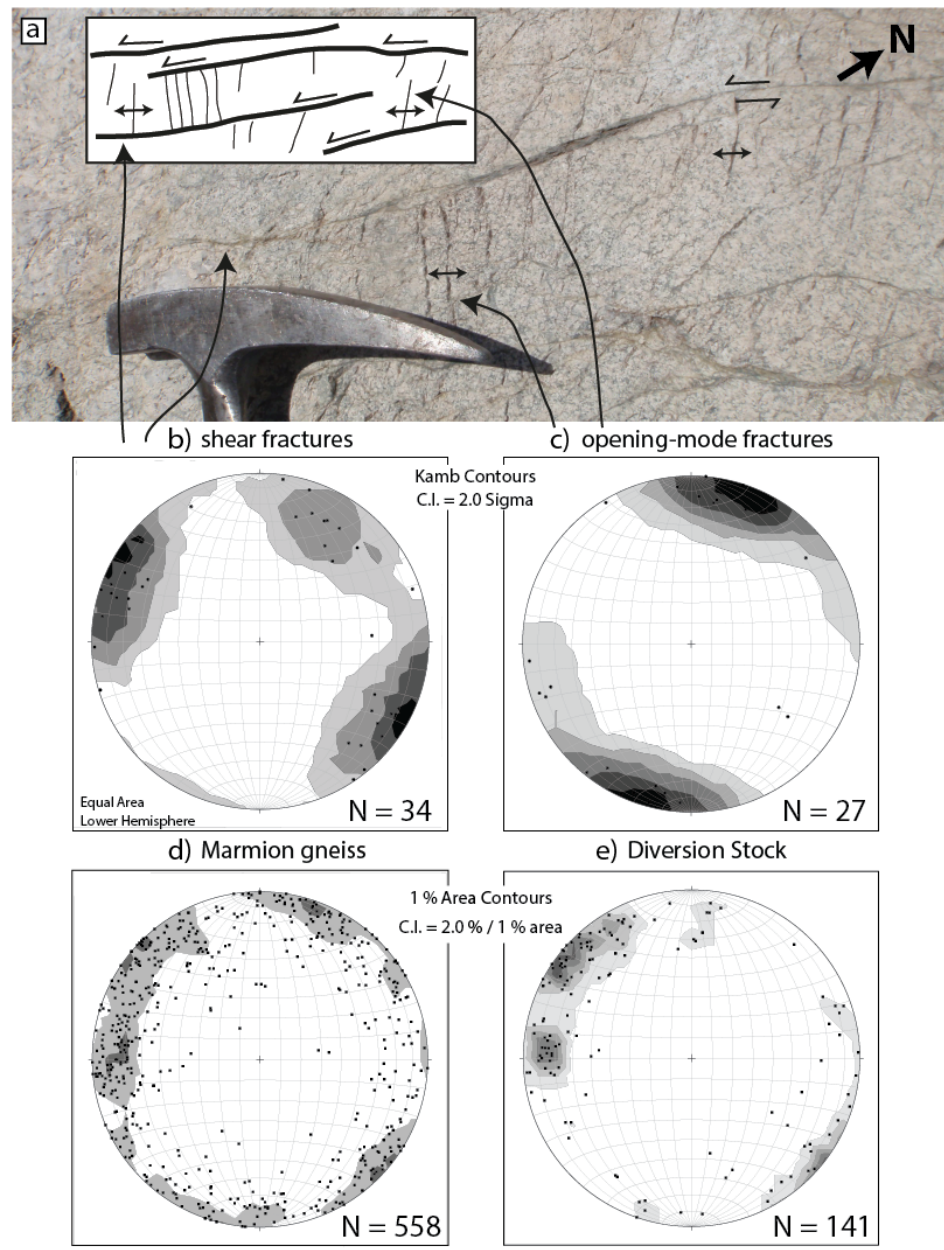

Figure 5: (a) Photograph of the fracture pattern in the Marmion gneiss. (b - e) Equalarea lower-hemisphere projections of fracture pattern preserved in tonalite lithons (see Figure $2 \mathrm{~b}$ ). defined by two perpendicular sets of long curvilinear sinistral shear fractures striking NNE and short, WNW trending opening-mode fractures that terminate along shear fractures. (a and b) Outcrops where both (a) shear fracture and (b) open-mode fracture sets are well exposed together. (c and d) Due to lack of exposure and weathering intensity, the fractures across the study area were mostly recorded as undifferentiated (see text). (c) Fractures measured in the Marmion gneiss, excluding the data presented in a and b. (d) Fractures measured in the Diversion Stock. 


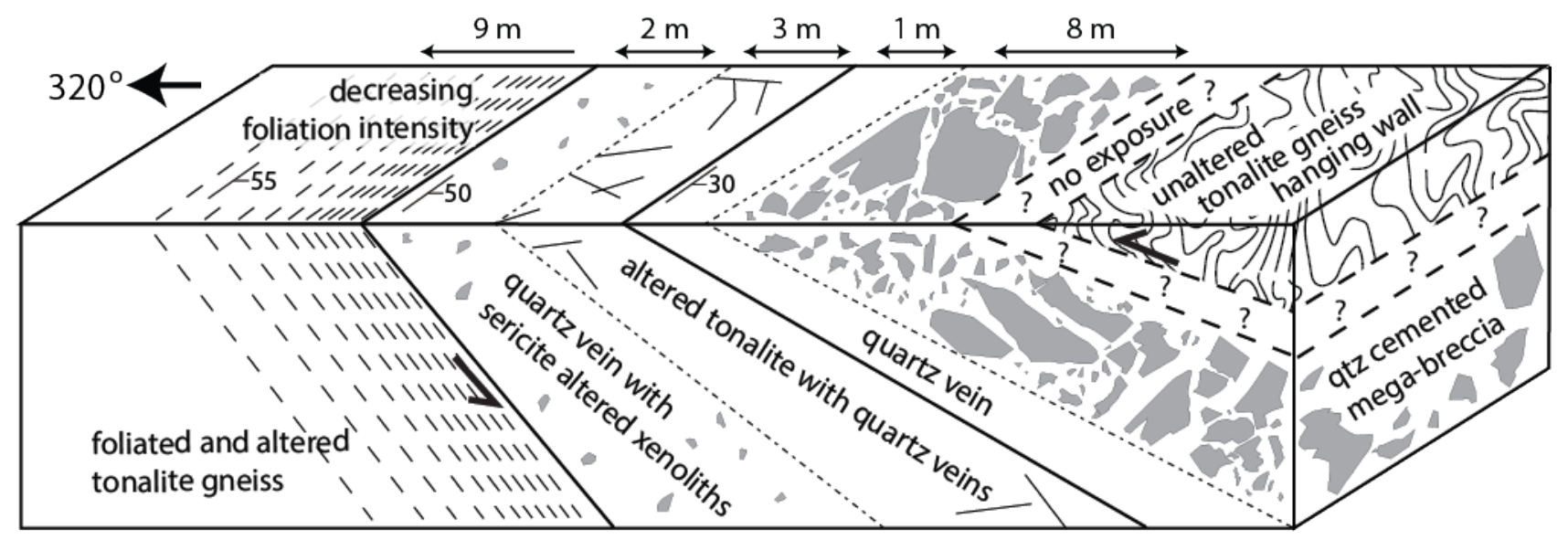

Figure 6: Fault stratigraphy of the Lynx Head Fault (LHF). The fault strikes $050^{\circ}$ and dips $30^{\circ}$ to the southeast, juxtaposing unaltered tonalites in the hanging wall next to altered, foliated tonalites in the foot wall. Two large quartz veins are emplaced along the fault. The lower quartz vein contains clasts of altered tonalite and the upper quartz vein contains coarse altered tonalite-clast breccia in its hanging wall. 

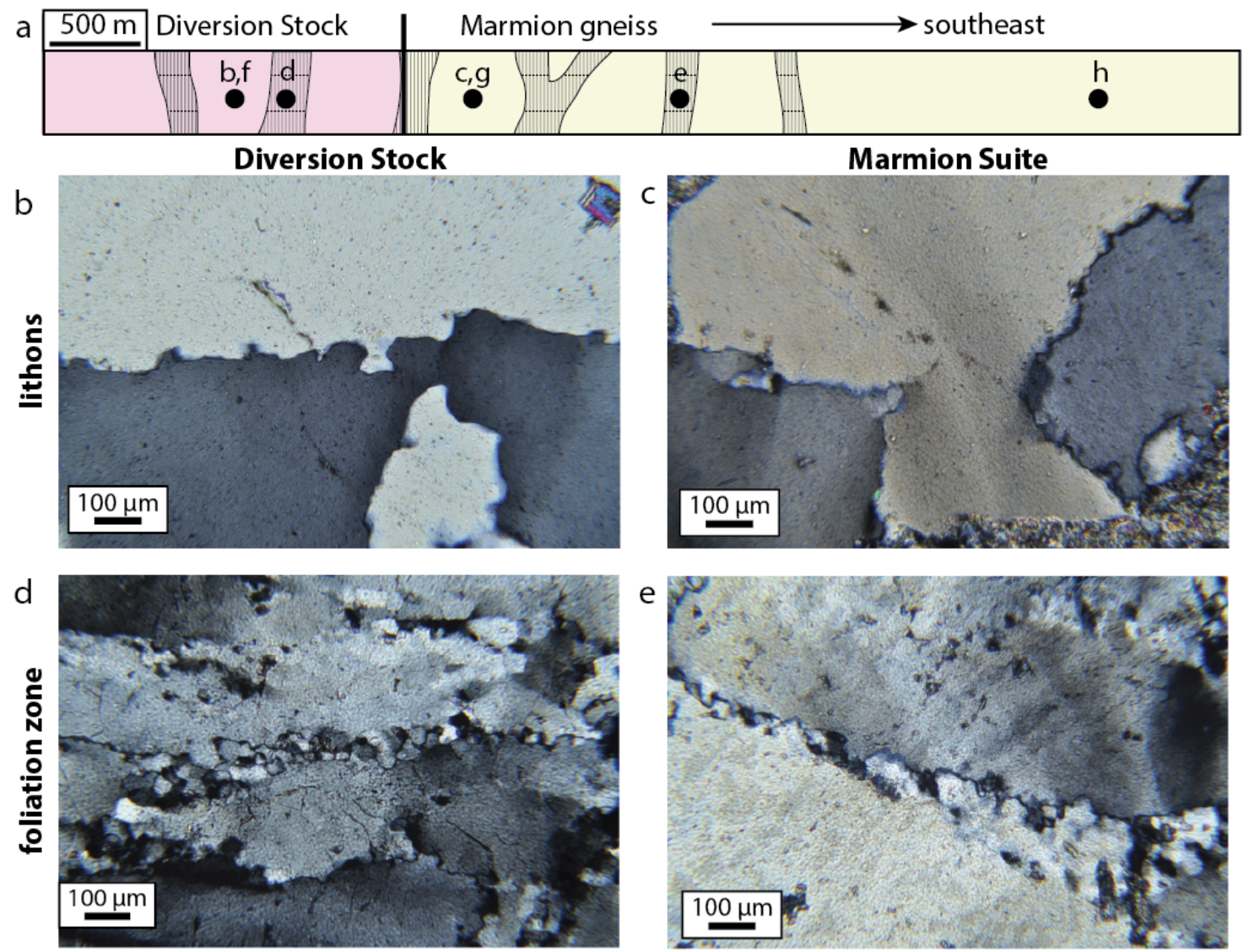

$\mathrm{f}-\mathrm{h}$ ) healed microfractures (fluid inclusions) density
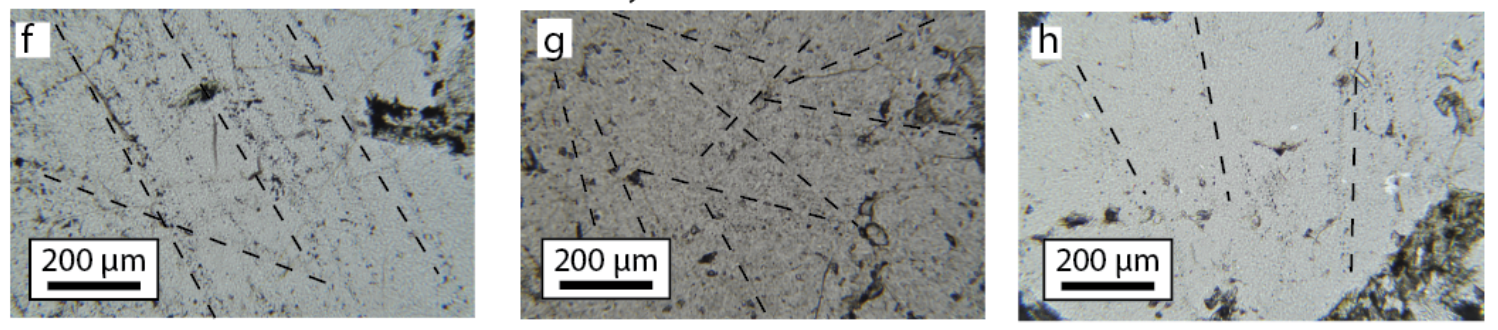

Figure 7: Photomicrographs of quartz rich zones in the Marmion gneiss (right) and Diversion Stock (left). (a) Cross section shows the relative position of samples within the anastomosing foliation (striped area). (b and c) Weak bulging recrystallization of quartzquartz grain boundary in unfoliated lithons of Diversion Stock and Marmion gneiss. (d and e) Quartz aggregates (microlithons) in foliated tonalites show more pronounced bulging recrystallization with sub-grain rotations along quartz grain boundaries. (f - h) Healed microfracture density observed by planar alignment of fluid inclusions (selected dashed lines aligned next to representative micro-fractures). (f) Moderate fracture density observed across the Diversion Stock. (g) High fracture of western Marmion gneiss, with a very high overall fluid inclusion density giving the quartz a cloudier appearance. (h) Lower (background) fracture density of Marmion gneiss away from the western margin. 

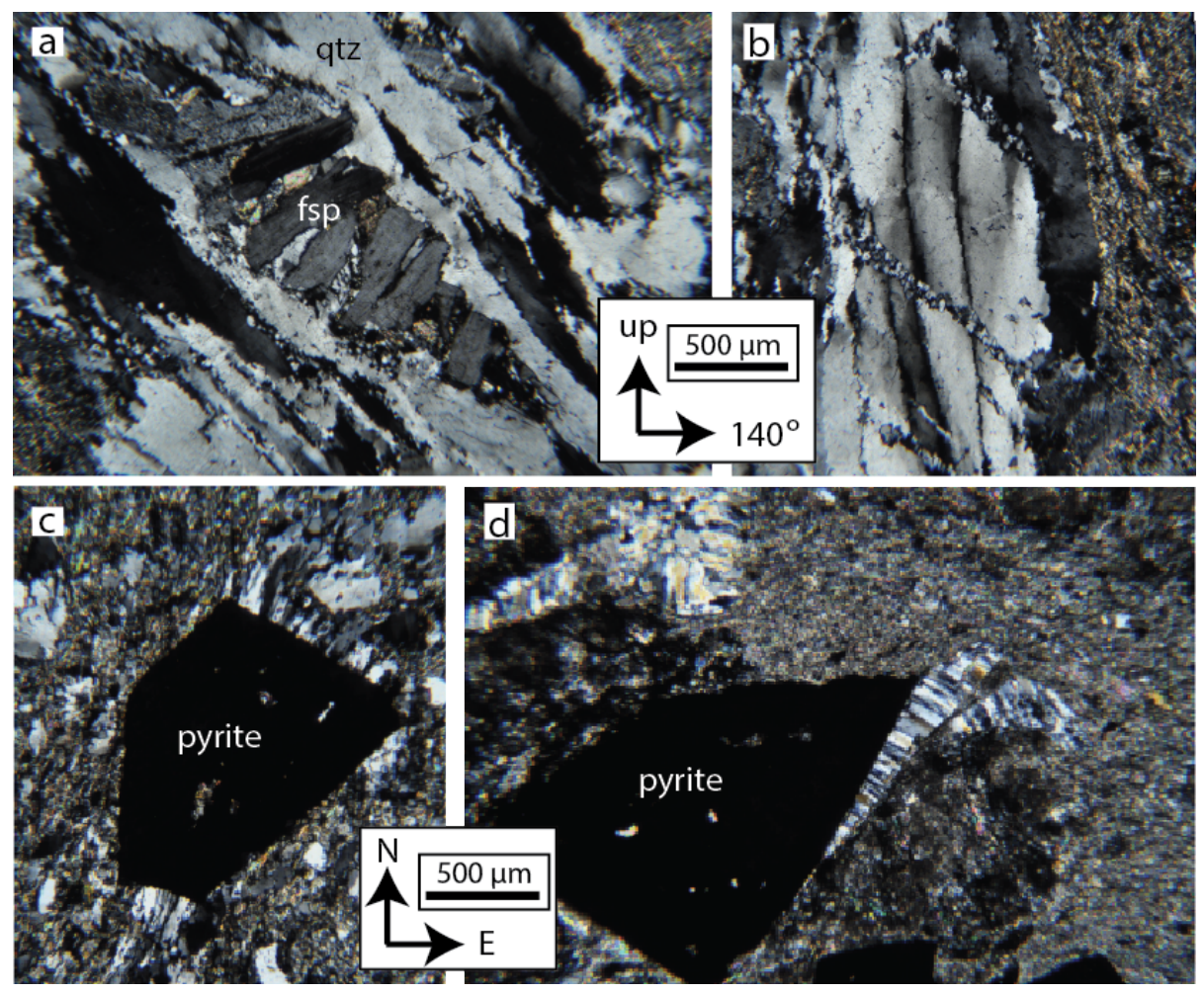

Figure 8: Photomicrographs of oriented thin sections showing (a-b) section views of quartzrich zones with bulging recrystallization within foliated tonalites and (c-d) plan views of quartz strain shadows around pyrite in foliation zones. (a) A zone of more shallowly dipping foliation, dipping $50^{\circ}-60^{\circ}$ to the southeast. Bulging recrystallization in quartz with preserved, fractured feldspar grain. The fractured feldspar shows extension perpendicular to the development of the bulging recrystallisation, consistent with flattening. (b) Bulging recrystallisation intersected at an angle by the foliation defined by aligned sericite. Bulging recrystallization is parallel throughout the thin section (a and b). (c) Symmetric quartz pressure shadows around pyrite and (d) pyrite with counterclockwise rotation. 


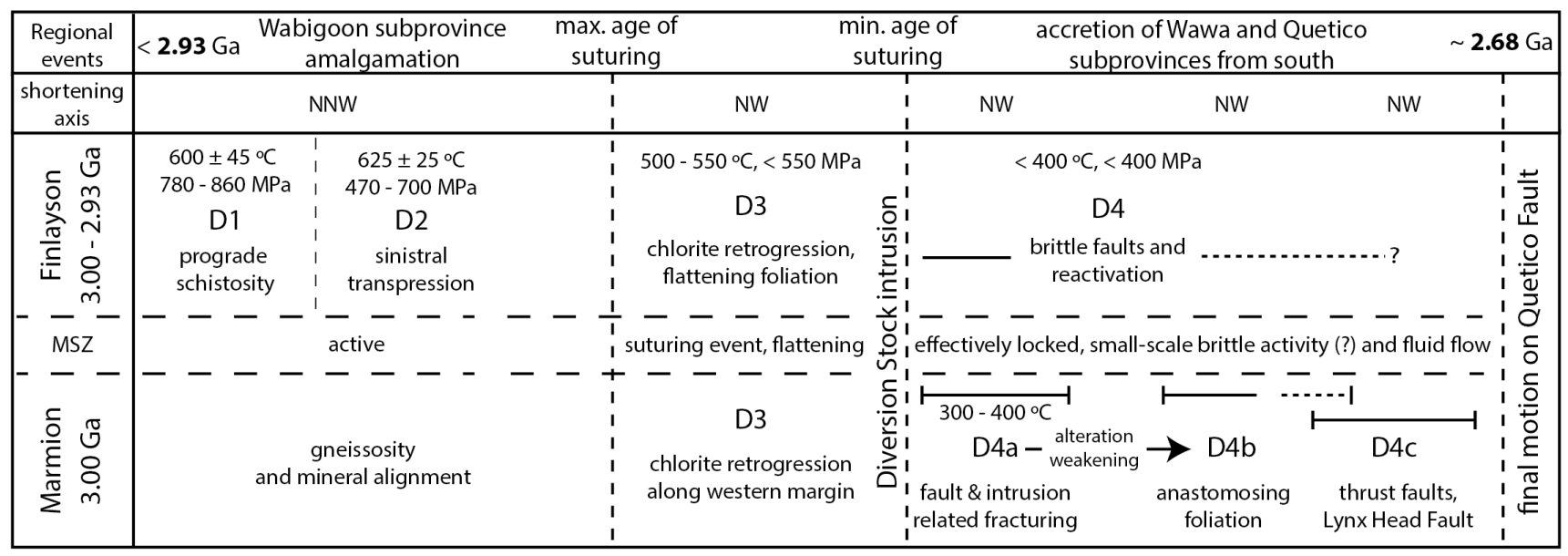

Figure 9: Summary of deformation history for the Marmion gneiss and Finlayson Lake greenstone belt. Question mark for the Marmion Shear Zone (MSZ) represents time where there are no constraints on the structure. Pressure-temperature estimates in greenstone belt taken from Backeberg et al. (2014). Maximum age of 2.93 Ga for $\mathrm{D}_{1}$ deformation taken from youngest depositional age in the Finlayson Lake greenstone belt (Stone, 2010). Latest fault slip along Quetico Fault at 2.68 Ga estimated from cross-cut intrusives (Corfu and Stott, 1986; Williams, 1990). 